\title{
The Dystopian Vision of the American Society as Reflected in Stephen King's The Long Walk (1979) Walaa Othman Diab Abdelmaksoud
}

\begin{abstract}
This paper focuses on the definition of dystopia, its development, and its function as a literary kind of writing. It shows how what seems to be utopian, on the surface, is in reality dystopian. Generally, in man's attempt to achieve a perfect society, dystopia appears in the abuse of power, manipulation, exploitation, and injustice. That is to say, this paper deals with how dystopian literature depicts the flaws of those seemingly utopian societies with reference to Stephen King's The Long Walk. It shows how young people fall victims to a game like the long walk which exposes their life to danger and even death to gain living for their lovely ones. In brief, it shows the slow decay of life and self.
\end{abstract}

Keywords: dystopia, utopia, cautionary, didactic, science fiction.

Dystopia: An Overview

Humanity seeks to find peace, order, and justice in a perfect world that is called utopia. Yet, this longing manifested in several literary works has been touched by the dark side of reality. Consequently, utopia is transformed into dystopia. Utopia is generally used to refer to the fictional representation of an ideal society, which is much better than the one in which we live. Such kind of society has perfect social, political and environmental systems. On the other hand, dystopia refers to the fictional representation of a society which is worse than the one in which we live. Thus, it can be described as an imaginary place or condition in which everything is as bad as possible (Moylan 95).

However, it should be noted that dystopia is not exactly the opposite of utopia, for both share the same intense measures of social control. The real difference lies in the approach. In both utopia and dystopia, the intense measures of social control emphasize extremely upon their positive and negative effects respectively. However, not all societies that are perceived as perfect represent utopia, but, in fact, they are the subtle beginning of dystopia. This is simply because all attempts to make those societies appear as perfect are made of power, manipulation, exploitation and injustice. This desire can generate greed and selfishness (Altaher 147). Anti-utopianists argue that a perfect society can only be achieved by force saying, "utopianism is said to lead to totalitarianism and the use of force and violence against people" (Sargent 75).

This means that there could not be a dystopia without the desire for a utopia (Dunn 47). So, dystopia exists when the society seems utopic, but 
when you look close enough, you can observe that it is not (Boyd et al. 38385). Accordingly, it can be confirmed that the turn to dystopian fiction is largely associated with the inadequate existing social, economic, and political systems.

Booker states that although the society of the United States seems to have been more successful and "durable", it has proved that it is greatly influenced by "serious abuse" of bourgeois capitalism (The Dystopian Impulse in Modern Literature 20). In fact, both utopian and dystopian societies aspire for a better future, but no society can be ever ideal for everyone. That is to say, a man's utopia can be another one's dystopia and vice versa. This is naturally because of the clashing and contradiction among humans' interests and desires. The world cannot be fair for everyone. Booker proceeds saying, "even these 'democratic' societies can have their nightmarish sides" (The Dystopian Impulse in Modern Literature 20).

The idea of utopian/ dystopian literature is derived from that of science fiction which is based on creating an imagined future to expose the human reaction to the contemporary changes in science and technology and their effects. Thus, dystopian fiction is set in the future to focus on the extreme destructive or negative effects of such changes. In fact, many dystopian works were strongly influenced by science fiction themes (Moylan xi- xv). Although science and technology are meant to enrich human life, this utopian impulse of science has been replaced by dystopian projections of disastrous current trends (Scholes and Rabkin 174). In dystopia, they are employed "to maintain the state's surveillance and control of its slave citizens" (Hillegas 3).

Beyond the obvious scientific changes, science fiction deals with the economic, political, and social changes that affect man and his life. Science fiction gives a space for a new form of political opposition within the bleakest conditions. Such generic fiction is considered allegorical descriptions of social injustice and a critique of societies (Moylan 30-32). Thus, fiction witnessed the advent of a new genre known as dystopia which offers a gloomy and bitter vision of the future, providing a picture of the present that is cast in the future (Cziganyik 305). However, dystopia presents a new way of understanding the world, which broadens the readers' experience towards the unseen possible reality. It might also prevent the status quo from being worse; as it presents an imaginary picture of the worst possible outcomes of the current conditions. It could possibly make people conscious of what might happen and therefore work to change it (Moylan 126).

Moreover, Booker clarifies that dystopian literature is used to provide future fresh and unfamiliar perspectives on problematic practices that might be inevitable. In this way, dystopian writings are read by many as political 
warnings. Booker proceeds saying, "This exploration of alternative perspectives obviously recalls the technique of defamiliarization"; that can be regarded as a literary technique of dystopian literature (Dystopian Literature 19).

Therefore, dystopian literature is made up of stories where the societies which seem utopian are revealed to be defined by the oppression and suffering caused by totalitarian or fascist government. Such government appears utopian only on the outside as its rulers think that this is the best for their nations. Nevertheless, the means by which they manage their state is unjust and wrong (Altaher 154). Simply, dystopia is not about a tyrannical society with limited freedom, but about what makes that society tyrannical. It is not simply about an evil police-state government, but it explores the way by which the government influences and controls people (Yoran 186).

A dystopian society is one where the government or some entity has robbed the population of their freedom. Dystopian societies are often characterized by dehumanization, totalitarian governments, environmental disaster, human misery, squalor, oppression, disease, and overcrowding or other characteristics associated with a catastrophic decline in society (wordreference.com). Those societies are class-based ones where lower classes are somehow forced to live in horrible poverty. Dystopian authors extrapolate the existing issues and amplify them to their extremes. Therefore, Sargent defines dystopia as a non-existent society, set in specific time and place, that a contemporary reader views as worse than the society in which he/she lived (9).

Being a genre of imagination, dystopian fiction presents an alternate reality in the future which is considered a cautionary tale or warning about the consequences of continuing certain policies or behaviors. So, dystopian works depict a negative view of "the way the world is supposedly going in order to provide urgent propaganda for a change in direction" (Clute and Nicholls 360-62).

The pessimistic future visions of the American society found in dystopian fiction from the middle of the 1960s to the present reflect the conflicts and the fears of the period before and during which they were written. From the early years of the American history, individual hopes, plans and ideas showed a tendency to be united into a complex configuration of ideas that were called "American Dream" (Shestakov 548). This American Dream expressed itself clearly during the 1920s, when America celebrated its financial prosperity. Yet, this era of hope and prosperity did not last long because of crashing the Wall Street stock market in October, 1929. This caused a lot of suffering as the American citizens struggled to cope with these difficult circumstances and many people were out of work as jobs were scarce. The United States of America then endured a decade of hardship and 
adversity during that state of the Great Depression (1929 - 1941) (Ayers et al. 698).

In fact, this period was clearly connected with great socio-economic and industrial changes that have required a new perception of the world. The dream of certain human progress through technological advancement was destroyed during World War I, and hopes of creating a better society faded with the Great Depression and the rise of "nationalistic totalitarianism" (Sisk 10). Consequently, the 1960s and 1970s was a time of opposition and challenges to the ruling class in the United States. However, the individual is powerless in the face of such bad conditions. In fact, the new imperial power of the United States removes any opposition by attracting people and tempting them with a better life which cannot be achieved any more (Moylan xiv).

In dystopian novels, the hopeful promise of the possibility of improvement is replaced by the notion that the world is a dangerously cruel and terrible place (Findley 56-57). Thus, the protagonists face famines, violence, and other forms of human oppression (Boyd 386). Among the most highlighted ideas in dystopian fiction are not necessarily horror or the apocalypse, but how one attempts to endure and survive "atrocities and frights" (McAleer 168). What distinguishes the dystopian writers is that they believe in man's ability to survive the worst conditions in which he lives. Although they acknowledge his defeat, they look beyond it to the possibility of winning (Woodcock 18-19).

As dystopian writers explore the dark side of their society, they adopt the approach of portraying an oppressive future society because it is often the best way to set a prophetic warning based on current abuses or disturbing trends in society (Borcherding 12). In other words, dystopian writings warn against, and didactically predict a coming evil while there is still time to correct the situation in reality (Sisk 80).

\section{Stephen King's The Long Walk (1979) as a Dystopian Novel}

Stephen King's The Long Walk (1979) is a great example of dystopian American writers. In fact, King stood on the scared ground of America; a man whose feelings about his country resonated through his fiction (Davis 2). Magistrale asserts that King "has supplied America with a national portrait", which is not always "a flattering one ... as it reveals our historical and cultural foibles and scars" (Preface to Stephen King: America's Storyteller $i x)$.

The Long Walk shows the darker and depressing side of his American society. It is marked with simplicity, as it has one event with no elaborate side stories. The plot revolves around an annual walking contest held annually on May $1^{\text {st }}$ by the American government. It has become a national sport. In addition, the roads are lined with thousands of spectators cheering 
the passing competitors and hopefully want to see the winner. In the Long Walk contest, one hundred teenage boys are selected randomly from a large number of volunteer applicants. The contestants are asked to walk as far as possible without stopping from northern Maine to Boston. The winner of such game will be the last survivor, who will get the 'Prize', which symbolizes everything he wants for the rest of his life.

At the time of writing The Long Walk, when King was in his early 20s, TV game shows were only a small number of what is out there recently. However, King was already envisioning a media-dominated future when cameras record everything. In fact, before the rise of reality TV with game shows, King has imagined an alternate history of the American landscape where an annual walking competition would become the nation's obsession.

Intended to be set in a dystopian future, King's imagination set the severe rules of the Long Walk contest, which include keeping the speed of at least four miles per hour. At the same time, if the contestant slows down again after receiving three warnings, he is "ticketed". The meaning of this action is intentionally kept vague at first, but it soon becomes obvious that it means to be shot dead by soldiers riding in half-tracks along the roadside. Those soldiers who are carrying "army-type heavy-caliber carbine rifles" are the same soldiers who have come around with canteens for the contestants (King 7).

As a totalitarian and a military-run government, the Major, who is the only leading figure of the game, implicitly sets the threat that if anyone wants to disobey him, he is going to be punished by death. Nevertheless, the contestants start the contest with a rosy vision of winning the game in their minds, especially when they see the welcome banners "WELCOME LONG WALKERS" on the sides of each city (King 12). In this context, The Long Walk questions what survival means through the eyes of one hundred boys who are walking into the arms of possible death.

In fact, in writing such dystopian novels, the writer concentrates on small groups of survivors, often showing them struggling and surviving the surrounded circumstances. In The Long Walk, after shooting some walkers, the other walkers have begun to be afraid, tired, exhausted, worried, and anxious. Consequently, they begin to express a collective hatred for the Major although they initially have greeted him with awe and respect. The tremendous cheer turned to "Diddly shit" (King 18). Along the novel, the walkers sometimes arrange themselves into small groups. For example, Garraty, the main character, puts all his negative feelings aside and forms bonds with several of his competitors especially Peter McVries, Arthur Baker, Collie Parker, Abraham, and Stebbins who refer to themselves as "The Musketeers" (King 123). 
Throughout the whole walk, the contestants talk a lot with each other, the thing which may produce a feeling of relief of their psychological struggle. It seems that everyone has his own dreams and hopes trying to fulfill them with all his power. In fact, King's trust in close-knit communities is shown in The Long Walk. It is a weapon by which human decency can survive to some degree even in the midst of the harshest struggle. This has been clear when Garraty's mother has asked him to leave the contest, he has insisted on joining such a deadly contest showing how ready he is to take any measures to guarantee his family a decent living.

Through the whole novel, the contestants have been almost protectively moving close together against the brutal nature of the competition in order to help their friends survive and put such feelings of fear and horror aside. In fact, during the whole walk, they encourage and push each other against the idea of death. In addition to the themes of love and humanity which characterize the novel, king presents collective resistance as the principal weapon to endure such totalitarianism and dehumanization. Magistrale defines such collective resistance as "a moral flight to freedom" (Landscape of Fear 8).

Nevertheless, perceiving the fact that others' death gives one a chance to win, some walkers have not been ready to help others. At the very beginning of their conversations, McVries once says to Garraty, "I like you ... But if you fall over, I won't pick you up" (King 13). In addition, another walker called Olson expresses his need for power to survive regardless of the means he uses. Later, he also spreads the feelings of horror among other contestants by telling them about the boy who was shot too early by the starting point in the Long Walk event which was held last year. It seems that he wants to frustrate the other competitors. Of course, such extreme selfishness can produce a dystopian world.

Cruelty and selfishness have been clear among other walkers, especially Gary Barkovitch who kept annoying his fellow walkers to the extent that he has caused the death of a walker called Rank as he is ticketed after repeatedly trying to attack Barkovitch who has kept annoying him. Consequently, all walkers consider him a "plague" and wish to see his death. While he is suffering and is about to die, Garraty says, "We'll all be glad to see you die. No one's going to miss you, Gary. Maybe I'll walk behind you and spit on your brains after they blow them all over road. Maybe I'll do that. Maybe we all will" (King 120).

In addition to the severe and undue rules, the totalitarian military system is evident in the strict constant surveillance or control of the contestants who are carefully bounded and watched by the cruel soldiers, who do not hesitate to shoot any contestant who fails to keep the specified speed (King 109). Moreover, when Garraty thinks that they can hide in the 
woods in order not to be seen by the soldiers, Olson replies that the soldiers have got "infrared sweepscopes, along with forty other kinds of monitoring gear, including high-intensity microphones. They hear everything we're saying. They can almost pick up our heartbeat. And they see you like daylight". As a confirmation of such control and surveillance, "a boy behind them [Garraty and Olson] was given second warning", although he was walking through the woods (King 41).

Upon shooting some walkers, the others are continually pressed against the idea of death and their own mortality. They have gradually begun to realize the fact that death is real and that they are going to die. Such feeling of pessimism is also clarified when Baker has asked Garraty about the prize and Garraty replies:

I don't see much sense thinking about it ... What if you won? What if you spent the next six weeks planning what you were going to do with $\ldots$ the Prize, ... and what if the first time you went out to buy something, you got flattened by a taxicab?

(King 22-23)

Indeed, it seems that the feeling of frustration and pessimism has begun to inflict most contestants gradually. They have begun to be afraid, tired, exhausted, worried, and anxious. McVries is one of the walkers who is mentally distorted because of his fear of death. This is shown when he has lit a cigarette although he is not a smoker and it is not allowed to smoke in the Long Walk. McVries' attempt to smoke may make the reader wonder whether it is an attempt to break the rules or to end his life, or whether he wants to shape his fate and end his life by his own free will.

Garraty, the protagonist, has kept thinking of the idea of death, who will die next? and what will they do with the bodies of the dead?, how will he die?, and what if he had been alive one second and dead the next? Actually, Garraty has too many questions and not enough answers. Olson also echoes Garraty's thoughts saying, "Why did I get into this? ... why did I let myself for this?" (King 44).

Indeed, in such circumstances, media plays a great role in the manipulation and dishonesty of authority. When the contestants have been asked about their opinion and their feeling towards the game, the reporter refuses to report their negative opinions, and makes "snipping motions with his fingers at the technicians" to keep only the voice of those who said that they feel strong, great, or okay (King 30).

As the severe rules, put for the game, suppress the freedom of the contestants, they reflect the theme of dehumanization. Sisk states that the individual freedom is suppressed in dystopia (2). More dehumanization appears in applying more severity than the set rules; as some walkers have been killed without a reasonable reason. 
In addition, the opening quotation in each chapter suggests the theme of dehumanization. Chapter 11, for instance, opens with "Come on, assholes! You want to live forever?" (King 97). Dehumanization is also evident in calling the walkers by their numbers not by their names. This indicates the loss of identity as the walkers themselves have believed that their names are no longer important. Dehumanization is also clarified when the soldiers who distribute the canteen ask the contestants to go to it by themselves as he says, "Go to it, boys!" (King 16). At that time, Garraty has been angry and that he is not respected as a human being. He has felt like yelling, "Why don't you just get up off your fat ass and go to it with us?" (King 12). What increases the sense of dehumanization is that the kind of food offered to the contestants was even worse than what they used to eat with their poor families.

Dehumanization is more evident in the scenes which are full of destruction and blood. Thus, Garraty has felt more worried, afraid, dehumanized and sickly thinks, "99 bottles of beer on the wall and if one of those bottles should happen to fall. Oh Jesus!" (King 16). His thought of describing the contestants as bottles reflects how dehumanized he feels. Moreover, while they have been walking, one of the contestants, Olson, once has described the walkers as, "More lambs to the slaughter" (King 4). As the walk goes on, the scene becomes more intense and bloody.

In addition, the walkers get astonished to feel how dehumanized they are by the crowd. The spectators indeed express their cheer when someone is shot at the time when the walkers think of their own private world of pain and effort. One memorable scene is when a 400-gun salute has been arranged at a mid-point of the walk to honor those who are still alive. The noise from the guns has been overwhelming and disgustingly has reminded them of the shots used to kill the slow walkers. Although it is depressing, exhausting and brutal, it is a beautiful story for the spectators to make them aware of how great it is to be alive. Clearly, the crowd becomes a metaphor of the alldevouring greed of the state, which takes no moral responsibility for human lives but, on the contrary, seeks to exploit them for the purposes of entertainment of the public and disposing of the poor (Strengell 198). Indeed, any totalitarian regime which imposes such "debasement" of the individual "might bring order into a disorganized world but at too high a price" (Theis 37). Therefore, those competitors can be regarded as the scapegoats of an attempt to create utopian world for only the political system. Magistrale states that this novel echoes the lack of social connectedness in the American society and the general spirit of carelessness (Landscape of Fear 7).

Being helpless and hopeless in such severe community increases the contestants' feelings of dehumanization, pessimism, disappointment, and frustration. The walkers' hopelessness is shown when Garraty says that he hoped to see his girlfriend again, Abraham exclaims saying, "Hope? Yeah, 
I'm beginning to remember how to spell that word," (King 130). It seems that they have completely felt disappointed and hopeless toward the end of the walk.

With the walkers' exposure to so much dehumanization, the reader becomes so astonished at the boys' desire to join such deadly contest. Indeed, no reason is clearly stated in the novel, but there are only clues to some of the reasons. Indeed, a few of them have a legitimate reason. For example, Scramm is aware that he has joined the long walk to get the prize for his wife and their future child. Also, Stebbins, who is the Major's illegitimate son, states that his intended prize is "to be taken into my father's [the Major] house" (King 138). However, most of the walkers admit that they don't really know why they are there. This also proves the idea that in numerous dystopias, the protagonists have no knowledge of who they are or of what they want (Theis 28).

Indeed, volunteering and joining such endurance and deadly competition has been an appealing option for those young men whose future looked to be less than rosy (Spignesi 110). The opening pages of the novel hint at Garraty's poverty which may be considered his main reason for joining such a game.

In fact, the poor economic conditions are not features of the protagonist alone, but also of the whole country. King narrates that Garraty's father used to describe Porterville, for example, as a "town in the country with more graveyards than people. But it was a clean place. The unemployment was high, the cars were rusty, and there was plenty of screwing around going on" (King 53). This description reflects the idea of dystopia in that although it is a clean place as it appears there are some other problems and issues inside such as unemployment and cheating.

During the walk, the contestants discuss some problems they face in their society, such as dropping out of school, the crowded schools, the lack of resources in the country, no insurance companies to support the long walkers, health problems, high prices, the income taxes, and the pollution problems. The walker Collie Parker sums up the very bad conditions of the country as he says, "I never seen such a fucked-up state" (King 82).

Indeed, trust in government has fallen dramatically. Garraty's mother has been worried about her son telling him that if his father were here, he would not agree on joining such game. The mother's opinion reflects and supports King's idea that the elderly become less trusting of the government due to the economic stagnation which leads to mistrust. Such feeling of mistrust also has inflicted McVries who describes the game saying, "It's a fake. ... There's no winner, no Prize. They take the last guy out behind a barn 
somewhere and shoot him too. ... Everyone loses, ... You better believe it" (King 52).

Although King displays the shortcomings of the American government, he shows that the walker's exposure to such dehumanization is not the responsibility of governmental authority alone. The walkers who choose to go on the game that leads to death share the same responsibility. As they are still teenagers, they are only tempted with the prize; anything they could ever want for the rest of their life! (Strengell 198). While the mystery of the prize may be a definite enticement, it helps increase the mental deterioration of the walkers. This is because each one of them thinks that he can beat the other 99 contestants. At the same time, he thinks that he is $99 \%$ going to be the one to die.

Later, the walkers have realized their mistake of joining such game. For example, one of the walkers Baker expresses his fear after hearing the gunshots saying, "Why did we do it, Garraty? We must have been insane.", and Garraty replies him saying, "I don't think there was any good reason" (King 125). Garraty sets his opinion of the game as, "the Long Walk is nothing but murder" (King 80). He becomes convinced that his mother has been right to advise him not to join the game. Garraty shows his regret saying, "I'd never do this again in a hundred thousand years" (King 102).

In this sense, it can be said that what seems to be a promise of a better life turns to be a means to get rid of the poor youth through a trick without much trouble. Instead of taking responsibility for its citizens, the state deliberately entices its best young men into such deadly game. Certainly, this reflects the meaning of dystopia as a fall of utopia. In this way, the individuals become against the authority, usually the government or the ruling class.

The Major now becomes a devil-like creature. Nearing the end of their endurance, some walkers scream for the Major hoping that their words will cause some sense of shame so that the killings will stop before they fall victim. Moreover, the walkers attempt to manipulate and break the rules. Pearson, one of the walkers tells Garraty that if he has got tired and could not continue walking, he would dive into the crowd so that the soldiers would not dare shoot; "I've made up my mind, though. If I get so tired and I can't go on, I'm gonna tun over there and dive into the crowd. They won't dare shoot" (King 102).

Nevertheless, much dehumanization sets a challenge to the human soul which is enslaved and man struggles for survival. In The Long Walk, the walkers' fear of death pushes them to follow the undue rules of the game in order to survive. When Stebbins has asked Garraty, "Are you going to hiss and boo?", Garraty replies, "No. Neither will anyone else." (King 52). 
Although fear makes people feel uncomfortable and overanxious, it is a vital element for survival (Davis 2).

In this sense, as human beings, every man strives for individuality and unique power to be the winner. Self-preservation or survival becomes the only purpose of the individual's struggle in such bad society (Magistrale, Landscape of Fear 7). Thus, toward the end of the walk, all walkers are infected by self-centredness and helplessness. Being afraid of death, Garraty regards himself as an animal, "Now, I'm an animal, nothing but a dirty, tired, stupid animal" (King 134). Of his own free will, he rejects humanity, represses the voice of conscience and answers the call for survival.

According to Magistrale, if such young people are to survive morally as well as physically - they must find a way to resist the prevailing values of a society and transforms themselves into monsters (Stephen King 142). Thus, even the innocent Garraty turns into a monster saying to one of his fellows, "I want to see you get that ticket. The sooner the better" (King 131). Later, he becomes more careless and rude. As he becomes fully aware of the true nature of the competition, Garraty feels alarmed and concentrates on getting to the top. That's likely why he wins the competition at the end.

The change of Garraty and other walkers from collectivity into individuality states the core of dystopian societies in which there is a fall from utopia. Life becomes a severe competition in which people should struggle to survive. This proves the governmental institutions failure to change the bad social economic conditions. The walkers are seemingly unable to change anything except to survive and win the game. They gradually become less hopeful for a better society.

Of course, such cruel conditions of the contest lead to physical and mental deterioration. Indeed, several walkers suffer mental breakdown from the stress and lack of sleep. For example, Barkovitch has killed himself by tearing out his throat. Such abrupt behavior makes the reader understand that life for Barkovitch has become much crueler than death. In such severe environment, "individuals are prepared to welcome death rather than life" (Theis 37).

The walkers are pushed beyond sanity while questioning the value of life in the midst of such suffering. Hoping he could get rid of such horrible life, McVries later wishes that he had been insane so that he could kill himself and end his life. He says, "I wish I were insane" (King 122). Moreover, some other walkers have already gone insane. Indeed, psychological and mental degeneration extends even to the winner of the game, Garraty. Although he wins the game, he feels that the hand of a dark figure touches his shoulder motivating him to keep walking as "he somehow found the strength to run" (King 148). This dark figure is only seen by Garraty. It is nobody in particular. It certainly indicates Garraty's loss of 
mind. Indeed, Garraty's victory is meaningless and useless, as he is now completely absorbed by the machinery of the state and lacks his own will. In this sense, Spignesi describes the competition as "the annual ritualized bloodlust torture of one hundred young boys" (110).

Actually, there is a downward spiral from the optimism of the first 10 hours to the torturous hell that is in the last 10 hours. So, the dystopian aspect actually lies in the slow decay of life and self as a result of the characters' struggle to survive such harsh conditions. In this novel, King depicts an alternate, possible fascist America. This America organizes competitions not to help its poor youth, but rather to get rid of them. Garraty says, "All we are is mice in a trap" (King 126).

The Long Walk is really a terrible version of real America. Although the format is familiar as games are common in some literary American works, The Long Walk is a great example of King's ability to take mundane things and turn them into sources of extreme terror (Kelleher 1-2).

To sum up, it can be concluded that the main dystopian feature of The Long Walk appears in that what is perceived as a means of helping the poor young men is revealed to aim at getting rid of them without much trouble. In addition to the dehumanizing and undue rules of the game, realizing that bitter fact of such games led to the physical and mental deterioration of all the contestants including the winner. In this way, winning such a game becomes useless and meaningless. In brief, it can be said that The Long Walk, as a dystopian novel, warns against the worst outcomes of living in such a society, which suffers from several problems such as poverty, unemployment, overcrowded schools, lack of resources, pollution, and mainly living in a country run by a military and totalitarian government. 


\section{Works Cited}

Altaher, Bassmah. "The Importance of a Dystopian Hero in Sara Gruen's Water for Elephants." International Journal of English Language and Translation Studies 1.2 (2013):146-166.

Ayers, Edward L et al. American Passages: A History of the United States. $4^{\text {th }}$ Ed. New York: Wadworth, 2009.

Booker, M. Keith. Dystopian Literature: A Theory and Research Guide. Westport, CT: Greenwood Press, 1994.

---. The Dystopian Impulse in Modern Literature: Fiction as Social Criticism. Westport, CT: Greenwood press, 1994.

Borcherding, David H. Science Fiction and Fantasy Writer's Sourcebook: Where to Sell Your Manuscripts. Cincinnati, OH: Writer's Digest, 1996.

Boyd, Brian, Joseph Carroll and Jonathan Gottschall, eds. Evolution, Literature, and Film: A Reader.. New York: Columbia University Press, 2010.

Clute, John, and Peter Nicholls. The Encyclopedia of Science Fiction. $2^{\text {nd }}$ Ed. London: Orbit Books, 1999.

Cziganyik, Zsolt. "Satire and Dystopia: Two Genres?" January, 2004: 305309. Researchgate.net Aug. 2018. 〈https://www.researchgate.net/publication/311825470_Satire_and_D ystopia_Two_Genres/link/585c346508ae8fce48facdcb/download).

Davis, Jonathan P. Stephen King's America. Bowling Green, OH: Bowling Green State University popular press, 1994.

"Definition of Dystopia." WordReference.com Dictionary of English. March, 2015 〈https://www.wordreference.com/definition/dystopia〉.

Dunn,Thomas P., and Richard D. Erlich. "A vision of Dystopia: Beehives and Mechanization". The Journal of General Education 33.1 (spring 1981): 45-57.

Findley, Mary. "Cultural Fears and Societal Mayhem in King's Fiction Since 1995" in Stephen King's Modern Macabre: Essays on Later Works. McAleer, Patrick \& Michael A Perry eds. North Carolina: McFarland \& Jefferson publishers, 2014.

Hillegas, Mark R. The Future as Nightmare: H.G. Wells and the Antiutopians. New York: Oxford UP, 1967.

Kelleher, Katy."Book Review: The Long Walk by Stephen King". February 15 2013. Web. December,2014. 〈http://www.literarytraveler.com/books/book-review-the-long-walkby-stephen-king/ .

King, Stephen. The Long Walk(1979). New York: Simon \& Schuster, Inc, 2016. 
Magistrale, Tony. Landscape of Fear: Stephen King's American Gothic. Chicago: Popular press, 1988.

---. Stephen King: America's Storyteller. Santa Barbara, California: Greenwood publishing group, 2010.

McAleer, Patrick "Surviving Ruin and Decay from the Stand to Cell" in Stephen King's Modern Macabre: Essays on Later Works. Patrick \& Michael A Perry eds. North Carolina: McFarland \& Jefferson publishers, 2014.

Moylan, Tom. Scraps of the Untained Sky: Science Fiction, Utopia, Dystopia. Boulder, Co: Westview, 2000.

Sargent, Lyman Tower. "The Three Faces of Utopianism Revisited". Utopian Studies 5,1 (1994): 1-37.

Scholes, Robert, and Eric S. Rabkin. Science Fiction: History, Science, Vision. New York: Oxford UP, 1977.

Shestakov, Vyacheslav P. The Origins and Originality of the American Culture. California: University of California, 1984.

Sisk, David W., Transformation of language in Modern Dystopias. Westport, CT: Greenwood Press, 1997.

Spignesi, Stephen J. The Essential Stephen King: a ranking of the greatest novels, short stories, movies, and other creations of the world's most popular writer. Franklin lakes: Career Press, 2001.

Strengell, Heidi. Dissecting Stephen King: From the Gothic to Literary Naturalism. Wisconsin: The University of Wisconsin Press, 2005.

Theis, Mary E. Mothers and Masters in Contemporary Utopian and Dystopian Literature. New York: Peter Lang Publishing Inc., 2009.

Woodcock, George. "Five Writers Who Feared the Future" New Republic. January 21, 2014: 17-20. Oct. 2015. 〈https://newrepublic.com/article/116276/george-orwell-anniversarydeath>.

Yoran, Hanan. Between Utopia And Dystopia: Erasmus, Thomas More, and the Humanist Republic of Letters. Lanham, Maryland: Lexington Books, 2010. 